\title{
The Perspective of Man in Islam and Christianity
}

\author{
Fathor Rasi \\ Centre for Strategic Studies, University of Indonesia, Indonesia \\ fath.rasi@gmail.com
}

\begin{abstract}
The aim of this study is to know the perspective of man in Islam and Christianity. The essence of human can be comprehend only through intuitive reason which is called intellectual or the Eye of Hurt (in Arabic word 'ayn al-qalb) rather than merely rely on discursive reason or the ratio. An effort to revive the divine dimensions in the hearts and behavior of modern man is very important to create a harmony and god relation between man and nature. Modern man has already melted in the mud of is his daily life and it's almost impossible to be near to the Spirit of his Lord. It can be concluded that any assessments, interpretations of all events and human phenomena cannot be accepted if placing human as a marginal entity or rim. By stating that man is a small nature (microcosm) and the nature is large man (the macrocosm) which has been direct manifestation of God's names, it has a significant meaning to the perspective and the relationship between God, nature and humankind.
\end{abstract}

Keywords: perspective; man; Islam; Christianity

\section{Introduction}

There have been much attempt to describe and to define human beings including in Islam. The discussion of human beings in Islam, both of philosophers and Sufis, is very dinamic and interesting. God has hinted in Quranic verses (al-Tîn: 4) that He has created man as the best creature (fî ahsani taqwîm). They try to reveal both the outer and the inner aspect of man, physical (body) and spiritual aspect (rūh) which is embeded in man. They try to dig the deepest meaning of the saying of Prophet "He who knows himslef knows his Lord" (man árafa nafsahu árafa rabbahu), and then they conclude that, it is impossible if we know our selves (the nature of human being) but then we deny God existence.

Even some of them try to compare between human and angel to show that man is the center of being. They said that the angels, for their all splendor, are 'peripheral' beings, in the sense that each represents a particular aspect of the Devine Plenitude: no single one among them reflects in his nature the totally of God attributes. Man, on the other hand, though far distant from the light of heaven, stands, as it were, directly beneath the Divine axis and mirrors Totality. That is why man, when his nature is fully developed and perfectly balanced, is described as a 'central' being, and this is why it is possible for him to be the khalifah of Allah on earth, the vicegerent.

The term of human beings, implicitly shows two entities, namely human which refers to the human body (body and mind), and being refers to the soul, human beings consist of two entities, namely body and soul (which is denied by many modern ideologies). An 80-year-old grandfather can remember his childhood. Yet according to biology, his current body is no longer like before when he was child, there are some changes of his cells, molecules and others. But surprisingly, although his body is not like before, in his childhood, he could still remember his state when he was child, it means his real "I" is actually his soul. So that, we can directly say that through his body, man is actually physical being, but through his soul, man is 
Konfrontasi Journal: Culture, Economy and Social Changes, 6 (2) July 2019, 8-17

P-ISSN: 1410-881X (Print)

Fathor Rasi, The Perspective of Man in Islam and Christianity

DOI: -

http://www.konfrontasi.net/index.php/konfrontasi2

a non-physical being who is independent of his body. According to the traditional views, the nature of human is non-physical being, which is called soul.

In addition, man has rational soul that only belongs to the human race. This rational soul allows and enables him to absorb rational premises, and its usefulness to guide, manage, and to master the forces of the lower soul. Thus man is the center of universe, and no wonder if man also called as a "microcosm being" because it contains of all the elements of macrocosm (the universe). Because of his special position, man is blessed by Spirit (rūh) which then cause him to have two dimensions that form two entities called al-nafs. Both of them are physical and spiritual elements. As spiritual beings man is able to do the things which can not be done by other creatures, such as receiving revelation (wahy) and divine inspiration (ilham), to continue life after death, to contemplate the abstract and to know ma'qūlat (the things that can only be understood intuitively not through the senses). Man is so special before God that is why He places him as His vicegerent (khalifah) on earth. No wonder if then Rumi call him as ultimate goal of the creation of universe. Of course, the ideal man who becomes the ultimate goal is His creations who has attained perfection (al-insan al-kamil) and it had already been shown by the Prophet Muhammad as a par excellence example.

\section{Review of Literature}

\subsection{Man in Islam}

Al-Ghazali states that, human beings have a fixed and constant essential identity, namely al-nafs (soul). What is meant by al-nafs is independent substance, space less and it is a place of knowledge, intellectual knowledge (al-m'a-qūlāt) derived from nature or malakut world or alam al-amr. He states that, the human essence is not physical or not physical functions. Because physical world is something that fill in a place, and its physical functions is dependent on the law of physic. So that, the essence of human is his immaterial substance which is independent. The nafs itself is idenpendent, spiritual, having ability to know and move, entirely different with the body. In addition, the view that the nafs is spaceless, apparently its related with hylomorphisme view which sees al-nafs as a form of the body. This perspective can bring to the conclusion that al-nafs ended his form with the cause of destruction of the body. Al-Ghazali rejected the view which say that al-nafs can be destroyed. Because $_{s}$ destruction of al-nafs will destroy the view of the existence of the hereafter.

The Qalb, as al-Ghazali calls it, is the essence of man. It is the spiritual entity which abides in his physical body and control his organic and physical function. Its call Qalb (heart) because it is connected with physical heart, though the connection merely transcendental. The spiritual heart is the substance and the physical only an accident. According to al-Ghazali the concept of the self I is expressed in Arabic by four terms; Qalb (heart), Rūh (soul), Nafs (desire-nature) and Aql (intellect or reason). Each of these terms signifies a spiritual entity. AlGhazali prefers to use Qalb for the self in all his writings. The knowledge of this entity is essential to the knowledge of the ultimate reality.

\subsection{Man in Christianity}

The general history of the views of man in Middle Age period in Europe that was dominated by church authority which emerged from the dogmas of Christianity. The Domination and the pressure of the church authority then raises awareness and new paradigm to reveal who the man is, which different with previous understanding. The emergence of a 
Konfrontasi Journal: Culture, Economy and Social Changes, 6 (2) July 2019, 8-17

P-ISSN: 1410-881X (Print)

Fathor Rasi, The Perspective of Man in Islam and Christianity

DOI: -

http://www.konfrontasi.net/index.php/konfrontasi2

new ideology in that period was unavoidable, a group of people who disagree with the concept of man under the church dogmas then joined in a movement which is known by "humanism." This new ideology requires the birth of the new concept of man as the measure of all things, and his freedom to determine their own fate and destiny with a strong self-confidence and demand more autonomy.

The spread of Christianity in Europe and the combination of the power of the Church with Roman Empire, the center of learning came under the influence of the apparatus of government to such an extent that by the sixth century (as was indicated previously) the universities and schools of Athens and Alexandria were closed. This period, which lasted for about one thousand years, is called the Middle Ages, and is characterized by the domination of the Church over the centers of learning and programs of the schools and universities.

In the beginning, the direction of medieval philosophy is the way of thought which is very different from previous thoughts. Philosophy in the Middle Ages is a new era, especially in the Western Europe. This new philosophy is called scholastic scholasticus in Latin means 'teacher' (Lecturer). In Greek, Scholes means 'school.' In historical cotext, Scholastic means the teachings of the church school, founded by Charlemagne, with the purpose of reestablishing religious teachings (Christian) that was damaged by the attack of Gaul, French, nation. However scholastic then used to signify a long period of western teachings, especially in the teaching of philosophy and theology, starting from the 9th century until the 15th century, and the charachteristic of skolastic views is its close relationship with Catholic theology.

Among the prominent personalities of this era is St. Augustine, who tried to use philosophical principle, especially the view of Plato and the Neo-Platonist to explain the dogmas of Christianity. After him, a number philosophical discussion, were included in the program of the schools. However, the attitude toward Aristotelian thought was unfavorable for it was considered to be opposed to religious beliefs, and its teaching was prohibited. With the dominion of the Muslims in all Andalus (Spain) and the penetration of Islamic thought in Western Europe, the Ideas of Islamic philosophers such as Ibn Sina (Avicenna) and Ibn Rushd (Averroes) were more or less discussed, and the Christian scholars also became acquainted with Aristotelian views by means of the books of these philosophers.

In general, the history of medieval philosophy is divided into three periods, namely the early scholastic (9-12 century), the glory of scholastic (14-15 Century). Early scholastic is an era where the main focus is aimed to make the systemic teachings of the Catholic. The Advancements during this period due to the teachings of St. Augustine, Neoplatonism and Aristotelian logic. While the glory of the century scholastic was in 13th century can be considered as the glory of scholastic philosophy and theology. In this century philosophy generally studied because of its relationship with theology. Then followed by the last period of scholastic which then emerged ideologies, namely Via Modern (modern view) as opposed to the group of Via Antiqua (Old view), this modern view led by William Okham (1285-1349) who began to reject metaphysical thinking constructively.

In the Middle Age period in Europe, as the views of Augustine (354-430) on man, which is also accepted by society at that time especially in Catholic religion, man is really exist, people close to God and regarded as His creations. Man was created in the image of God, there is spiritual aspec within man, human beings won't be vanish when the body is dead, because his spirit would remain survive, man was created by soul and body. In the medieval period man concepts are not separate from the religius teachings and dogmas. Little by little, members of 
Konfrontasi Journal: Culture, Economy and Social Changes, 6 (2) July 2019, 8-17

P-ISSN: 1410-881X (Print)

Fathor Rasi, The Perspective of Man in Islam and Christianity

DOI: -

http://www.konfrontasi.net/index.php/konfrontasi2

Church could not resist this wave of philosophical thought, and finally St. Thomas Aquinas accepted most of Aristotle's philosophical views which are reflected in his own books, and gradually, opposition to Aristotle's philosophy decreased, and even came to dominate some centers of learning. The emergence of the new movement is inevitable which is later known as "Humanism". The term humanism is derived from humanitas, which means human education. In the Greek language is called paidea.

\section{Discussion}

\subsection{The perspective of Man in Islam}

The fundamental views of man found in both philosophy and mysticism. In Sufism, the study of human beings, especially the idea of Perfect Man, technically emerged in Islamic literature in early 7th century. Then the idea of Ibn Arabi (D.638 H), they use the term to label the ideal concept of man who becomes the locus of God. Human beings are created from God's spirit (al-rūh) then it's breathed into human being. The rūh which is brethed into human has angelic nature, like illumination, mildness, consciousness and unity. So that human deserves tobe the most perfect being compare to the other creatures. God creates him in accordance with His form. But the attributes which is given to human is only all the names which is only only potential. Therefore many of them don't know His names. Because God creates human through two elements namely good and evil.

Philosophy and Sufism discuss the issues related to God, the Absolute truth-which includes haqîqah, existence, perfection, the beginning of creation and end of life. In this series, the conversation then extend to the nature and the concept of man, including his relationship with God and another creatures. Islamic philosophy and mysticism generally view human beings comprise of two substances, physical (body) and spiritual substances (soul), and that the real essence of man is his spiritual substance. The majesty and the perfection of man is obtained by enabling the spiritual substance by sharpening the forces he had.

Islamic Philosophy uses term al-Nafs to signify immaterial substance. Al-Nafs itself has special forces, and most importantly, for philosopher is the rational soul through process of reasoning and intellection within the nasf. Human perfection is obtained by sharpening this rational soul. By sharpening rational soul in order to enable man to connect himself directly with the al-Aql al-Fa'al (Active Intellect) that is the source of knowledge. Sharpening this force is found in every epistemology, Islamic philosophers like al-Kindi, al-Farabi and Ibn Sina.

In Sufism, the term al-rūh and al-qalb are used to signify immaterial substance of human. By this immaterial substance, the Sufis strive to achieve the highest level of perfection so that they gain knowledge about the haqîqah of the Supreme Being through al-Dzawq, as the most important force and source to unite with Him. In mysticism, reason ('aql) is not important and significant because the efforts of self-perfection is not through intellectual process, but sharpening the powers of intuition and emotion. Beside the differences in viewing the most important force and self-improvement efforts, there are also other important differences between philosophy and mysticism. The forces-owned by human have its effectiveness on himself, in the view of the philosophers. Human beings have free will and ability to achieve everything they do. In Sufism, all motion and human action is due to God's will and because of the force created by Him then all of actions in human is actualized. 
Konfrontasi Journal: Culture, Economy and Social Changes, 6 (2) July 2019, 8-17

P-ISSN: 1410-881X (Print)

Fathor Rasi, The Perspective of Man in Islam and Christianity

DOI: -

http://www.konfrontasi.net/index.php/konfrontasi2

A number of philosophers and Sufis in Islam says that, that human soul is a spiritual substance that is originally located in the essence of truth and has nothing to do with body. But then God created physical being (body) to be occupied by the soul so that it is separate from the original essence. Soul completes body whose position is like animal, something that is influenced by terrestrial dirt. The more he is still in the world, the more it will depend on the other, until his chance to live in this world is end, then it will return to its origin, the soul then leaves the body, and returned to his original world, the spiritual world.

Rumi, like other thinkers, believes that human beings comprise of body and soul, body and soul be supposed to the rays and the soul itself be supposed to shadow. Body is an instrument for the development of the soul where the body's life is much depend on soul's life. Rumi agrees with the second opinion in which the human soul is included to spiritual being which is originally located in the essence of truth and has nothing to do with body, it always gives life to the good.

To Rumi, the "Perfect Man" is the manifestation of God. Divine Light spark the heart which undergoing mystical world. To see himself is to see God. In other words he is a mirror which reflects God, His name, and His atribute perfectly. Furthermore, Rumi asserts that, its impossible if the essence and reality of God appeare in the material world and His creation, His essence and atributes is not from material world and from His creation. The manifestation is only a representation, hence, is owned by the creatures in accordance with its existence, the things in material world and all creatures are able to reflect God in the world based on the level of their existence and capacity where human beings have the capacity to reflect God more than another creatures, that is why human being deserve to get the title of His Khalifah (vicegerent) on earth as the most perfect creature.

In Islam, especially among the Sufis, man is viwed as the image (or created through the image) of God. He is the divine prototype, amid of his reduction, through scientific research, into animal level. The concept of man in Islam is never separate from God because man himself is the image of Him. God's existence encompass this universe including in the world of al-Nafs and al-Ruh are under His coverage.

The spirit which is mentioned in the Qur'an, As was asserted by Ali Syari'ati, is the "Divine nature" and the sorce of life as the engine which generate and blew forces in such amazing shape through its unique character and form, like Israfil's trumpet which is able to resurrect dead bodies their graves, in order to start new activities which is completely different with the previouse life. Islam places a man in the Tauhīd, in which God, man and nature, are in harmony and have meaning. In Islam, with the assumption that the essence of human origin is clay, which is then breathed spirit into it as a manifestation of God that lies between matter and something sacred. Islam acknowledge the existence of duality in human existence, the divinity of earth elements and elements which then become the values in life.

According to Murtadha Muthahhari, man is endowed by innate nature. Innate nature does not mean the actual existence of certain amount of understanding or the actual existence of certain tendencies and desire in him from his very birth, or as philosophers say that man is born with rationality and will. Similarly Islam does not accept the theory of Marxist and the Existentialist who deny the existence of innate nature and say that man is born like blank sheet and is equal receptive to any idea which is printed on his mind. According to Islam in the beginning of the period following his birth, man has certain potential tendencies towards the realization of which he wants to move. An inner force drives him toward his goal, of course with the help of external conditions. If he actually achieves what is befitting of him, he secures 
Konfrontasi Journal: Culture, Economy and Social Changes, 6 (2) July 2019, 8-17

P-ISSN: 1410-881X (Print)

Fathor Rasi, The Perspective of Man in Islam and Christianity

DOI: -

http://www.konfrontasi.net/index.php/konfrontasi2

what is called humanity. If an actually other than that imposed him by compelling external factors, he becomes a deformed being. That is the only plausible explanation of the metamorphosis of man of which even the Marxists and the existentialist talk.

The spiritual and moral formation of man is on stage subsequent to his physical formation. His body is formed in the womb by the creation factors. But his spirituality and moral systems and the components of his personality have to be developed later. As such every man is the builder and engineer of his own personality. The brush that paints the personality of man has been given in his own hand. Separation between anything other than man and its nature is unimaginable. A stone cannot be separated from its stonness. The same is true of a tree, of a dog and a cat. Man is the only existing in the case of which there is a difference between himself and his nature and between man and his humanity. Many men have not been able to attain humanity some barbarians and nomad have stayed in the state of animality.

Murtadha Muthahhari argues that existentialists have maintained the correct philosophical explanation by making existence as the basic principle and view that man himself who chooses his nature. The Muslim philosophers, especially Mulla Sadra, have laid ample stress on this point. It is with this view in mind that Mulla Sadra said, "Man does not belong to on single species; but is multispecies being. In fact an individual may one day belong to one species and anther day to a different species."

From here, it becomes clear that, most of Islamic philosopher and Sufis admit the existence of soul which now has been eliminated by modern science. Some of phylosophers and Sufis in Islam say that, that human soul is a spiritual substance that is originally located in the essence of truth and has nothing to do with body. But then God created physical being (body) to be occupied by the soul so that it is separate from the original essence. Some of them also said that soul completes body whose position is like animal, something that is influenced by terrestrial dirt. The more he is still in the world, the more it will depend on the other, until his chance to live in this world is end, then it will return to its origin, the soul then leaves the body, and returned to his original world, the spiritual world.

\subsection{The Perspective of Man in Christianity}

The term of humanism has a fairly complex history. In the history of its development shows hostility toward religion, especially Catholic as the religion of the majority at the beginning of its emergence. This new ideology gets its sympathetic support bacause it introduced new important concepts such as humanum (humanity), human dignity, human rights and other matters which then tend to be more man-centered.

This word is popularized in the era of Cicero and Varro. As for humanism in the Middle Ages to the 14th century is a philosophical movement that arose in Italy and developed throughout Europe. Humanism asserts that man is the measure of all things. Human greatness should be revived, which had been buried in the medieval period. Therefore, the legacy of classical philosophy must be returned and the legacy left by mid-century must be revised. Human freedom is the central theme of humanism. Pico as one of humanism views that man was awarded the freedom of choice by God and created him as the center of world. Therefore, by this position and privilege, man is free to view and choose the best.

In the sixteenth century, the interest in the natural and empirical sciences became intense, and the discoveries of Copernicus, Kepler and Galileo shook the foundations of Ptolemaic all aspects of human affairs were subjected to disturbance and instability. The papal 
Konfrontasi Journal: Culture, Economy and Social Changes, 6 (2) July 2019, 8-17

P-ISSN: 1410-881X (Print)

Fathor Rasi, The Perspective of Man in Islam and Christianity

DOI: -

http://www.konfrontasi.net/index.php/konfrontasi2

institutions were able to withstand these roaring waves for quit some time, and scientists were brought before the Inquisition with the excuse of their opposition to religious dogmas, that is, for their views on natural philosophy and cosmology which were accepted by the Church for the exegesis of the Bible and religious doctrines. Many were burnt in the fires of blind fanaticism and selfishness of the authorities of the Church. However, eventually the Church and papal institution were forced to withdraw in shame.

The ruthless fanatical behavior of the Catholic Church had no effect but to give the people a negative attitude toward religion, and likewise the downfall of scholastic philosophy, that is, the only current philosophy of that period, brought about an intellectual and philosophical vacuum, and finally the appearance of modern skepticism. During this process, the only thing that made progress was humanism, and a desire for natural and empirical science in the cultural area, and a tendency toward liberalism and democracy in the field of politics.

Humanism is a philosophical movement which tries to place humans in a special position, as well as making him as a measure of all thing. In the beginning of its history, humanism is an ideology which encompass of literature, culture, thought and education, but it then has shown its growth and tend to be more socio-political nuances. Therefore, most of all schools of political thought, ethics, art, literature and the political system were mastered. In other words, whether we realize or not, humanism has been taught to all aspects of society. Each like communism, utilitarianism, spiritualism, individualism, existentialism, liberalism, until protestanism of Martin Luther King (Christian Protestant), using the same formula associated with humanism. And the spirit of humanism has infected them.

Humanism merely means related to human beings or concern for human beings. Humanism generally takes a nonreligious stance, saying that there is no world or life beyond this one and that human beings everywhere are responsible for creating out of this life the most moral. As a humanist, one cannot pass off the immortality or destructiveness of this world on God or disobedience of human beings toward God, but must take the responsibility of fighting it everywhere and eradicating it only through human efforts.

The Views of humanism comes from ancient Greece namely Socrates who directs his philosophical consciousness on ethical awareness on how to raise human dignity as an individual and society. This is the essence of the humanism that formed the history of European thought and culture. Socrates's Humanism then influenced early Christianity that tried to include the best ideas from Greek and Jewish traditions. Jewish and Christian tradition in the beginning was much concerned with ethics. There is a story that Jesus asked to describe the Jewish Torah which he replied that it is about loving God and neighbor. Similarly, Rabbi Hillel taught the same thing in Yarusalem.

There is a harmonious union between religion and humanism during the Renaissance period. But then some enlightenment philosophers desputed the union between religion and Renaissance humanism, such as Dennis Dederot, Voltaire, Baron d'Holbach, David Hume and others. They felt there was something wrong in Christian dogmas nad the government at the time was controlled by Christian power. Because of the mistakes made by Christian leaders, the enlightenment philosophers wanted to reform of these errors by placing the government on the foundation of human rights. Those thinkers understood what had been done by Newton in physics through the discovery of natural law and they also want to place culture and human society upon it. Their mission is to bringback to place human and society on his nature (fitrah). 
Konfrontasi Journal: Culture, Economy and Social Changes, 6 (2) July 2019, 8-17

P-ISSN: 1410-881X (Print)

Fathor Rasi, The Perspective of Man in Islam and Christianity

DOI: -

http://www.konfrontasi.net/index.php/konfrontasi2

Here we can see the conflict between religion and humanism. The View of early human values as proposed by the Christian ethic has disappeared. There are some diputes and conflics among religions which appeared later, such as conflict between Catholics and Protestants. A group of philosopher at that time tried to identify the problems, as occured in French and British people, which were caused by religion. Then major conflict between church and state has depicted the conflict of religion and state. That is the history of Europe which later led to the birth of separation between religion and state in the United States two hundred years ago.

The Mistakes made by church authorities had serious consequences. Catholic as a religion in the Middle Ages was seen as an absolute religion, which later when it stepped on the beginning of the modern period was considered as enemies of humanism. Man who has original sin and the tragedy of his deportation from paradise, considered as a being who was forced to submit totally to the will of God, and as an oppressed being on earth, as well as labeled him sinner and accursed being, except for those who have authority like pastors who were viewed as a figure having "the Spirit of God", and the only way to happiness is by following their pastors guidance blindly, and join with the official institution which is controlled by a formal institution on behalf of God representative on earth.

In medieval period, as the pastors became the only judge to solve the problems of religion as well as theology, unuvoidable baseless and unsteady ideas then emerged which is opposite and irrelevant with the reality. Usually, this is not only scientifically satisfying and enlightening the people, but also creates hatred to religion and all of thought of theistic views.

Muthahhari has argued that the Church played an important role in delivering humankind to be anti-God. This happens due to the imposition of the of various teachings, views, scientific doctrine, and ignorring people of the freedom to choose their own belief. The Church, devorce from its true teachings, has added a series of scientific doctrines of man and the universe. The scholars at the time then slowly adopted the roots of Greek philosophy and various schools of philosophy. Mutthari also quoted Will Durant who said that, the number of victims between the years 1480-1488 exceeded 964948800 were burned and brutally tortured. And between the years 1480-1808 that burned more than 31,912 and 291,450 cruelly punished.

As a result, according to Syari'ati, such mindsets has caused theism becomes the opponent of humanism. And for the sake of realization of God's exalted, compulsively, such mindsets were implemented over the school of thoughts which makes humanism as an oppressed victim. Therefore, humanism in the middle age was oppressed marginally. Therefore, the artistic and aesthetic phenomena in medieval period was an expression of metaphysical paintings and what lies behind human nature: the Holy Spirit, Jesus Christ, Angels and so on.

The emergence of humanism has demanded more opportunity, at least we will mention the two most important factors in this problem. One hand some characters of religion and church systems, such as the weakness of the principles of theology and Christian value system, prioritazing the faith (heart) in understanding over (ratio), the deviation of Christian teaching such as original sin, buying and selling heaven, opposition against science and reason, and unreasonable compulsion of the church over the scientific results and ratio, has created a factor and the condition of alienation from the ruling of religious systems at the time, namely Christianity, and encouraged them oriented to the Romans and Ancient Greeks which more respect for human and his intellect. 
Konfrontasi Journal: Culture, Economy and Social Changes, 6 (2) July 2019, 8-17

P-ISSN: 1410-881X (Print)

Fathor Rasi, The Perspective of Man in Islam and Christianity

DOI: -

http://www.konfrontasi.net/index.php/konfrontasi2

Most of the humanist who has relationships with the centers of authority along with their views, that religion is a seriouse barrier for all of their interests, intends to find a way out to uphold the leadership of the previous groups. They provide a rational explanation of political development and modernism. Toni Davis phrase that, they make justifications and excuses for the savagery of modernism and the war against religion, values, all of what is considered sacred and respected by religion and the church system as a manifestation of their efforts. They always try to ruin the view of society to accept the necessity of separation of religion from social and politics. These factors, has led to separation between religion away from the social-political sphere. During the tention, the emergence of new interpretations of religion, God, and statements to reject religion and Christian teachings is unavoidable. In addition, the doubts to religion, religious diversity, tolerance among religions, values and everything that is considered sacred by religion, Protestantism and the acceptance of various new interpretations of religious teachings, as well as the acceptance of various new interpretations of the teachings in religion, were also emerged. Man's natural instincts were killed in order to liberate mankind from original sin. The life in this universe is entirely sacrificed for it.

Humanism viewed that one cannot rely on other power supernatural being for the creation of a better world: people living now and this earth must take any changes that are to be made to improve the world. Because of this point of view, humanistic alternative must be found to Judeo-Christian ethics, which are based mostly on the existence of the supernatural. Humanism therefore ground their ethics and empirical evidence only, and not alleged supernatural commands or prohibition. They emphasize the empiricism and logic of the science and philosophy to try to improve this world and allow for all the positive human values, such as freedom, security, happiness, progress, and peace, to come to fruition.

This school of thought, in general, is obsessed from ancient Greek and Roman culture, and tend to be non-spiritual ideology. They associated with of social elite class, and in the the of 13th century emerged in Italy, then spread throughout the entire Italy. After that, Germany, Franch, Spain, and England, those coutries couldn't escape from the influences. It can be said that this humanism movement is one of factors that caused the emergence of a new culture in the Western world. Humanism in this sense is the most important and fundamental teachings of the Renaissance. Renaissance thinkers were trying to interpret human being and renewing the concepts of human in term of material world and history, by placing him as a measure of everything.

As was mentioned before, humanism intend to return the spirit of Roman and Ancient Greek. Man's ability and potentiality in the Roman and Ancient Greek got special attention, but during the Middle Ages was it was disregard. So in the new atmosphere, all the values and teaching of Ancient Greek should be revived. They assume that, serious effort to revive the learning activities, as well as socialize knowledges such as mathematics, logic, poetry, history, ethics, politics and in particular Greek and Roman literature, capable of placing man as a free and creative being, so he has a big chance to use his freedom. Therefore, people who socialize the knowledges or at least they help to facilitate in implementing such learning and socialization, called as humanists. .

Humanism views human beings is as a product of evolution and history. By this way, for the adherents of this groups, human values, including happiness, progress and peace can be reached. Man is now no longer a spiritual creature who has the origin as was described by the holy books of religion. 
Konfrontasi Journal: Culture, Economy and Social Changes, 6 (2) July 2019, 8-17

P-ISSN: 1410-881X (Print)

Fathor Rasi, The Perspective of Man in Islam and Christianity

DOI: -

http://www.konfrontasi.net/index.php/konfrontasi2

Since Renaissance era, Western man has pride of himself upon of his independence, if upon nothing else, and this independence is closely bound up with a spirit of rebellion against God, against destiny and against the very nature of things. Prometheus stole fire from heaven; he did not wait to be given it, and Prometheus is the model. Here we can see conflict between religion and humanism. The human values as proposed by religion like Christian ethic has disappeared. Then major conflict between church and state has depicted the conflict of religion and state. Finally this humanism led to nothing but to the freedom of man of God, then he identifies himself as a measure of all things.

\section{Conclusion}

Man is the center, so every reality must be returned to man himself. Thus, any assessments, interpretations of all events and human phenomena cannot be accepted if placing human as a marginal entity or rim. By stating that man is a small nature (microcosm) and the nature is large man (the macrocosm) which has been direct manifestation of God's names, it has a significant meaning to the perspective and the relationship between God, nature and humankind. According to the Ikhwan al-Safa, both have similarities. If humans as microcosm created by combination of two substances at once, i.e. the physical body and the simple substances that have certain spiritual creative power, then so does the universe as macrocosm.

\section{References}

Ali Syariati, Humanisme antara Islam dan Mazhab Barat, (Bandung: Pustaka Hidayah, 1996), second edition, p. 73

Amsal Bakhtiar, filsafat Agama, (Jakarta: Logos Wacana Ilmu, 1997), p. 121

Ignace Lepp, Ateisme Dewasa Ini, terj. (Yogyakarta: Shalahuddin Press, 1985), p. 68. See also

TH. Huijbers, Manusia Mencari Allah, (Yogyakarta: Kanisius, 1982), p. 156-159. Compare to Harry Hamersma, Tokoh-tokoh Filsafat Barat Modern, p. 64-65

Louis Leahy, Aliran-aliran Besar Ateisme, (Yogyakarta, Jakarta: Kanisius dan BPK Gunung Mulia, 1985), hal. 90-91. see also Francisco Budi Hardiman, Filsafat Modern: Dari Machiavelli Sampai Nietzsche, p.229-231

Harun Hadiwijono, Sari Sejarah Filsafat Barat 2, (Yogyakarta: Kanisius, 1980), p. 120

Hamid Parsania, Existence and the Fall; Spiritual Anthropology In Islam, (London: ICAS Press 2006), p.2

Jacques P. Thiroux, Philosophy theory and practice, (New York: Macmillan Publishing company, 1985), p. 122

Bayraktar Bayrakli, Eksitensi Manusia: Perspektif Tasawuf dan Filsafat Mengatasi Problema Eksistensial Manusia Jalaluddin Rumi Sampai Filosof Kontemporer, translated. Suharsono (Jakarta: Perenial Press, 1996), p. 1-2

Seyyed Hossein Nasr, Traditional Islam in the Modern World, (London and New York: Kegan Paul International, 1987), p. 100-101

Budi Hardiman, Filsafat Modern: Dari Machiavelli Sampai Nietzsche, p. 64

Poedjawijatna, Manusia dengan Alamnya, (Jakarta: Bina Aksara, 1983), p. 85

Muhammad Taqi Misbah Yazdi, Philosophical Instructions: An Introduction to Contemporary Islamic Philsophy, p. 11 